\title{
Non-Governmental Organisations Personnel, Social Workers and Religious Leaders' Perspectives on the Risk Factors of Alcohol Abuse Amongst the Youth: The Case of the Northern Region of the Republic of Namibia
}

\author{
Rapholo Selelo Frank ${ }^{1}$, Makhubele Jabulani Calvin ${ }^{1}$, Ananias Janetta Agnes ${ }^{2}$, Svinurai Anesu ${ }^{1}$, Hasheela Miriam \\ Winnie $^{2}$, Hamuse Tiberia Ndanyakuwa Ilonga ${ }^{2}$, Freeman Rachel Johanna ${ }^{2}$, Mafa Prudence ${ }^{1}$, Matlakala Frans \\ Koketso $^{1} \&$ Chilwalo Beatrice Namoonga ${ }^{2}$ \\ ${ }^{1}$ Department of Social Work, University of Limpopo, Sovenga, South Africa \\ ${ }^{2}$ Department of Social Work, University of Namibia, Windhoek, Namibia \\ Correspondence: Prof. J.C. Makhubele, University of Limpopo, Private Bag X1106, Sovenga 0727, South Africa, \\ E-mail: Jabulani.Makhubele@ul.ac.za
}

Received: July 29, 2019 Accepted: October 7, 2019 Online Published: October 15, 2019

doi:10.5539/gjhs.v11n12p55

URL: https://doi.org/10.5539/gjhs.v11n12p55

\begin{abstract}
This qualitative study aimed to explore and describe the perceptions of Non-Governmental Organisations personnel, social workers and religious leaders on the risk factors of alcohol abuse amongst youth in the Northern region of the Republic of Namibia. In order to pursue this aim, a multiple case study design was used. Substance abuse is a predominant social and health problem which calls the attention of different partners from different disciplines across the globe to address it. Substance abuse, in particular, alcohol abuse is a global concern particularly amongst youth. Youth indulge in alcohol abuse due to numerous risk factors. Semi-structured interviews were used with Non-Governmental Organisations personnel, religious leaders and social workers who were purposively selected. Findings revealed familial, the environmental and community based and socio-economic factors as predisposing youth at Oshikango to indulge in alcohol abuse. It is therefore concluded that there are lot of opportunities at the Northern region of Namibia which predispose youth to engage in alcohol abuse. Thus, stakeholders need to develop integrated strategies to fight the abuse of alcohol amongst youth in the Northern region of Namibia.
\end{abstract}

Keywords: alcohol abuse, Namibia, risk factor, youth

\section{Introduction}

Alcohol consumption is a health and social problem causing many undesirable outcomes globally, including the Republic of Namibia. According to World Health Organisation [WHO] (2011), the consumption of alcohol is a serious health and social burden amongst youth. Young people are amongst the most abusers of alcohol across the world (Guillen, Roth, Alfaro, \& Fernandez, 2015; Salanta, Tofana, Pop, Pop, \& Coldea, 2018). Many countries have established policies and programmes to reduce the level of alcohol drinking amongst youth. However, youth still continue to indulge in alcohol abuse due to various risk factors. The WHO (2011) postulates that alcohol is a causal factor in 60 types of diseases and injuries and a component cause in 200 others and that almost $4 \%$ of all deaths globally are attributed to alcohol, greater than deaths caused by HIV/AIDS, violence or tuberculosis. Furthermore, there are a range of problems as a results of alcohol consumption such as violence, child neglect and abuse, and absenteeism in the workplace which can cause devastating impacts on the individuals and their families which may ultimately end up affecting the entire community and the world at large (Constantinescu \& Constantinescu, 2012; Salanta et al., 2018). The consumption of alcohol in the Southern Africa in predominantly high and the republic of Namibia has been reported as having a large reported cases of alcohol abuse (Ananias et al., 2019). Given that youth amongst others are the most alcohol consumption group, this paper aimed to explore the risk factors of alcohol abuse from the perspectives of NGOs personnel, social workers and religious leaders in the northern region of the Republic of Namibia. 


\subsection{Background Information and Problem Formulation}

The trend of substance abuse has been alarming in the developing and developed countries in the past decades (Lynskey et al., 1999; Jernigan \& WHO, 2001; Parry et al., 2004). The abuse of alcohol and other illegal substances is expeditiously growing in the Sub-Saharan countries such as South Africa and Namibia and has become a public health and social concern for youth (Meghdadpour et al., 2012). The South African National Drug Master Plan of 2013-2017 (SA, 2013) stipulates that alcohol abuse continues to devastate families, communities and society. Alcohol and drugs damage the health of users and are linked to rises in non-communicable diseases including HIV and AIDS, cancer, heart diseases and psychological disorders. There is a growing concern about the excavating problem of socially unacceptable and violent crimes committed by young people (Kachur et al., 1996; Lowry et al., 1998; Allan et al., 2001; Blumstein, 2002). In Namibia, Oshikango in particular, there is limited research on alcohol abuse as well as the nexus between alcohol abuse and health and social ills such as domestic violence, assaults, and risky sexual behaviours, amongst others. The researchers have also noticed that there is dearth of data on different types of substances used by people from Oshikango in the Ohangwena region of Namibia. Therefore, there is a need for research in this region so that an intervention in terms of prevention and treatment can be contextualized to the conditions of the region in general and Oshikango in particular.

Youth indulge in alcohol abuse due to various factors. Brook et al. (1998) established that for example, parenting and family factors such supervision and attachment, and environmental stressors have an influence on youth's alcohol consumption. The other factor which makes youth to indulge in alcohol consumption is the involvement with negative peer groups (Dishion et al., 2010; Robinson et al., 2016). Robinson et al. (2016) postulate that social context exerts a very strong influence on alcohol abuse. To emphasise this notion, Thrul and Kuntsche (2015) denote that there more alcohol consuming peers one keeps, the more likely one ought to drink alcohol as well. In addition to these factors which lead youth to be at risk of consuming alcohol, Babor et al. (2010) maintains that the history of substance abuse within the family is a major risk factor for drug use and alcohol abuse disorders amongst youth. Youth who come from families which have a history of alcohol abuse are more likely to drink alcohol as well. The drinking behaviour becomes part of their lives and later influence the entire community where they live in. This has been validated by Komro et al. (2007) who found that for some youth, to drink alcohol is not just because on interpersonal factors, rather alcohol consumption is a practice from the communities where they come from and mostly in their households. The Commercial availability of alcohol within the communities is also identified as a risk factor for youth to indulge in alcohol abuse (Forster, Murray, Wolfson, \& Wagenaar, 1995). This include amongst others, the price and/or alcohol content of the product (Scribner, Mackinnon, \& Dwyer, 1995). If alcohol is sold at a less price, youth find is easy to access it and later engage on the drinking behaviour. Sometimes people indulges in drinking behaviours because of domestic problems. This was confirmed by Grayson and Nolen-Hoeksema (2005) that when people encounter traumatic events within their households, the more likely they are to indulge in alcohol abuse to deal with what they are going through. They use drinking as a coping mechanism. To add on this notion, Macy, Renz and Pelino (2013) also found that a considerable number of partner abuse violence experience substance abuse problems. In order to address alcohol abuse globally, various practitioners and academics from across disciplines have joined their efforts. To this point, the researchers have developed an interest to establish from the perspectives of NGOs personnel, social workers and religious leaders in the Northern region of the Republic Namibia on the risk factors of alcohol abuse in a Namibian context.

\subsection{Aim of the Study}

This study aimed to explore and describe risk factors of alcohol abuse amongst youth in Northern region of the Republic of Namibia from Non-Governmental Organisations personnel, social workers and religious leaders' perspectives.

\subsection{Theoretical Framework}

The eco-system theory was used in this study to describe and explain circumstances and conditions relating to the risk factors associated with alcohol abuse amongst the youth. The researchers explored and described youth alcohol abuse within the context of the rural setting of the republic of Namibia. This theory appropriately helped to explain the relationship between substance abuse, in particular, alcohol abuse, and systems in which youth interact with. Substance abuse amongst youth is one way or another influenced and impacted by both the environment and its inhabitants thereof. According to Franklin and Jordan (1999) and Karger (2000), eco-systems theory is also called the life model which provides the guiding framework for understanding practices. The eco-systems theory asserts that the systems are always sub-systems of the larger systems in an environment, but can, at the same time, be divided into smaller sub-system units. These subsystems according to Potgieter (1998) influence each other behaviourally. To view alcohol abuse by youth in isolation from their family and environment according to the 
ecosystems theorists is tantamount to ignoring the influence of the home in which they learn to perceive how they fit in the world, as well as the influences others have on their behaviour. Any risk behaviour that an individual may manifest or display, threatens the balance of the family of origin where roles and perceptions are nurtured. The ecosystems theory provides a framework wherein researchers can understand the mutual relationship between the person and the environment in which each shapes and influences the other over time. It plays a fundamental role in grasping the problem of concern within the situation of the person in context.

\section{Research Methodology}

This study was qualitative in nature wherein a multiple case study design was followed in order to explore and describe NGOs personnel, social workers and religious leaders' perspectives on the risk factors on alcohol abuse amongst youth in the northern region of the Republic of Namibia. Exploratory research assist researchers to gain a broad understanding of a situation or phenomenon under investigation (Bless \& Higson-Smith, 2000). It addresses the "what" question (Neuman, 2000). On the other hand, the descriptive research assisted at describing the risk factors associated with alcohol abuse amongst the youth in Oshikango which is in the northern region of the Republic of Namibia. It focuses on "how" and "who" questions and enables researchers to provide a detailed, highly accurate picture of the background and context of the participants and/or participants situation (Neuman, 2000). Semi-structured interviews were used with three religious leaders, five NGOs personnel and two Social Workers in Oshikango. Purposive sampling was used to select the targeted population of this study, however, the availability and convenience of the participants were taken into consideration. Data was organized and managed through Nvivo software and was analysed thematically. Braun and Clarke (2006) postulate that thematic data analysis is widely used in qualitative studies in order to develop well-structured themes and sub-themes.

\subsection{Ethical Issues}

Ethical concerns are considered as an integral part of research. Researchers are responsible for designing and carrying out research both knowledgeably and ethically (Milley et al., 2001). In this study, an ethical clearance and permission were granted from the ethical review committee of the University of Namibia and the Ministry of Education, Arts and Culture and Turfloop Research and Ethics Committee and Musina Local Municipality, Limpopo Province in South Africa as this was a joint study between the University of Limpopo and the University of Namibia. A consent form which was explained to all participants was signed to allow them to voluntarily participate in this study. Participants were assured that their names and identities will not be stated on this paper in order to ensure their confidential matters and maintain their anonymity.

\section{Discusion of the Findings}

The following themes and sub-themes emerged from asking participants on the risk factors on alcohol abuse amongst youth in the northern region of Namibia:

\subsection{Family Discords and Stress}

Social workers and NGOs personnel indicated that because of relationship problems within young people' households, youth opt to abuse alcohol in order to relieve their stress. This was confirmed by Matlakala (2018) who found from his study in South Africa that young people indulged in alcohol abuse due to stress within their families. When young people feel psychologically overwhelmed, they are more likely to abuse alcohol in order to relieve stress (Brady \& Sonne, 1999; Jackson, Knight, \& Rafferty, 2010; Shilakwe, 2005; Thobejane \& Raselekoane, 2017).

The other participant echoed that:

"I also think the issue of relationship with parents. If you are not in good terms with your parents you, you are bound to stay out and during that, also lead to alcohol abuse and turn into alcoholic in order to relieve stress. The poor relationship between parents and young people at home predispose them to resort to alcohol abuse".

Findings depict that family discords between young people and their parents overwhelm young people with too much stress that they resort to alcohol in order to get relieved. It is therefore imperative for parents to pay attention to their relationships with their children as that has an impact on predisposing young people to alcohol abuse, and of course later into ant-social behaviours. This notion supports what Fergusson and Horwood (2000) and Matlakala et al. (2019) have established in their studies that young people who abuse alcohol are more likely to fall prey of anti-social activities.

\subsection{Accessibility of Alcohol Within the Home Setting}

From the three categories of data, Social Workers and NGOs personnel depicted the accessibility of alcohol within the home setting in the form of home brewed alcohol as another risk factor which predispose young people in the 
northern region of Namibia to alcohol abuse. These participants have shown that in Oshikango which is in the Northern region of the country, the home brewed alcohol is prevalent and that from very young ages, children do even sell this traditional alcohol on behalf of their parents. Social Workers have stated that young people coming from such families drink even in the presence of their parents because to them it is normal.

The other participants stated that:

"...........And there are also those that are have their business in their homesteads where they brew alcohol. In that instances, young people watch it being prepared and it becomes available for them”.

In the same wavelength, the other participants mentioned that:

"They are introduced from very young age most of the young people especially in this area they have home brew, tombo (traditional home brewed alcohol) at home, so....it is acceptable for them to drink. It is not really that they are not allowed to drink tombo. They drink even if the parents are around. So, I think that is where they start first drinking at home. Sometimes kids are the one selling it at home after school and some they don't go to school".

Alcohol which is being prepared within the households becomes easily accessible for youth and ultimately predisposes them to the abuse of alcohol. Matlakala (2018) has found in his study on risk factors on alcohol abuse in Musina, South Africa that, when young people get access to alcohol, they are more likely to abuse it. Therefore, home brewed alcohol is mostly accessible as it is available within the household.

\subsection{Drinking Parents}

Religious leaders have alluded that some youth grow up in families where parents drink alcohol excessively. Observing a parent drinking alcohol is risky in the sense that the observer might intends to do the same. This is supported by Maree et al. (2008), Mudhovozi et al. (2014), Matlakala (2018) and Ndondo (2016) who postulate that youth have a tendency of imitating inadequate role models such as their parents, caregivers and guardians. If such role models abuse alcohol, youth is more likely to engage in the drinking behaviours as well. United Nations Development Programme [UNDP] (1999) substantiates this by highlighting that the way children are brought up, drinking habits within the families and parents sending children to alcohol outlets to buy them alcohol, results in such children seeing the consumption of alcohol as a way to live.

In corroboration to the above, one pastor stated that:

"Let me add on that one that many parents are also misusing drugs and alcohol in the presence of their children, and some also share the alcohol with their children. Unfortunately kids end up using the same substances".

Findings show that parents who drink alcohol are risk factors for their children, in this case, youth, to indulge in alcohol abuse, more especially if they do not have restrictions to them. Hayes, Smart, Toumbourou and Sanson (2004) posit that children who grow up from families where their parents frequently abuse alcohol are at risk of abusing alcohol as well.

\subsection{Peer Pressure}

Some pastors, NGOs personnel and social workers raised peer pressure as a risk factor for youth in the northern region of Namibia to indulge in alcohol abuse. These participants have indicated that young people learn about alcohol abuse amongst themselves and observe others drinking and do likewise. Matlakala's (2018) study in South Africa, validates this notion wherein peer pressure was identified as a risk factor on alcohol abuse amongst youth. The other pastors indicated that the social associations with which a young person can find him or herself in, have an influence on their drinking behavior. This supports Robinson et al. (2016) who postulate that social context exerts a very strong influence on alcohol abuse.

This is a response from one pastor:

"To most of them peer pressure is also the channel for them to abuse alcohol. When we are seating like this and you all are using drugs, the possibility is that you will influence us you see. Most of them are influenced by that. Because my friend is using it I can also use it".

In the same wavelength, the other NGO personnel stated that:

"Peer pressure. Like if my friends are going out and me I am drinking coldrink I am forced to drink also alcohol just top satisfied my friends".

Findings strongly depict peer pressure as a risk factor on alcohol abuse amongst youth at Oshikango. The researchers are of the view that young people should be vigilant in choosing friends. To support this notion, Dishion, Véronneau and Myers (2010) and, Robinson et al. (2016) aver that the involvement with negative peer 
groups makes youth to indulge in alcohol consumption. To emphasise this notion, Thrul and Kuntsche (2015) denote that there more alcohol consuming peers one keeps, the more likely one ought to drink alcohol as well.

\subsection{The Proximity and Accessibility of Liquor Outlets}

Most participants from the three categories of data raised a concern about the proximity and accessibility of the liquor outlets which are all over the Oshikango community which is in the northern region of Namibia. They have mentioned that such liquor outlets make alcohol and other illegal substances easily accessible to youth in their community. The notion of the accessibility of alcohol is supported by the previous studies by Shikoyeni (2017), Kauaria, Kaundjua and Mufune (2015) and Nowak et al. (2018) who found that alcohol is easily accessible all over Namibia and that it increases the drinking behaviour amongst the Namibians, particularly youth. Ananias et al. (2019) has also found that most residential areas in Namibia have liquor outlets which are not far from each other and that they increase youth's accessibility to alcohol.

One participants echoed that

"I think you have observed that the area is full of coca shops and bars which are closer to each other especially when it comes to young girls they have relationships, sometimes they have taxi drivers who supply for them, and they meet some guys at the bars, and when they go to the bars they do not drink tombo".

In the same wavelength, the other pastor stated that:

"After every house second house there is a bar, you don't know what type of bars they are. Some have tombo. Every okambashu is having a corner of tombo".

Findings reveal the proximity and accessibility of liquor outlets at Oshikango as a risk factor for youth to indulge is alcohol abuse. This is supported by Ndondo (2016) and Milam, Lindstrom-Johnson, Furr-Holden and Bradshaw (2016) who assert that the availability of alcohol in close proximity of liquor outlets may tempt youth to engage in drinking behaviours. When the area is full of liquor outlets which are not far from each other, youth are more likely to indulge in alcohol abuse. It can be noted that there is a serious breaking of the Liquor Act No 6 of 1998 of Namibia which has a clause stating that, as far as possible, the establishment of licensed liquor outlet, more especially around schools or places of worship should be avoided (Government of the Republic of Namibia, 1998, 16 A iii).

\subsection{Social Events (Weddings)}

Social events, weddings, in particular were stated as risk factors for youth at Oshikango to indulge in alcohol abuse. Social Workers have indicated that from their caseloads, most youth were introduced to alcohol abuse at the weddings and that became their habits. This confirms the study findings by Patrick et al. (2015) who conduct a study amongst students and found that such youth indulge in binge drinking when attending parties and other entertainment social events which are more likely to be on weekends.

This is what the social worker asserted:

"Oh... my opinion, okay, according to the information that I know from my caseload, they also getting it from the events like weddings".

It can be noted from the findings that social events happening within the communities have an influence on the drinking behaviours of young people. Young people in that instances have an access to alcohol. This is in line with what Masemola, van Aardt, and Coetzee (2012) have found that if young people can find themselves in an environment wherein there is an easy access of alcohol they are more likely to drink.

\subsection{Porousness of the Border}

Some pastors have stated the openness of the Oshikango border post which is bordering Namibia and Angola as a risk factor for alcohol abuse amongst youth at Oshikango. These participants have alluded that the border is not thoroughly monitored as people are able to cross without legal documents. It was stated that young people cross the border with alcohol from Angola.

This is a response from one of the pastors:

"Mainly other challenges we have is that Angola currency is now down and we are sharing the border. Most of alcohol is passing through the border. When you go to the open market there and in Angola there is a lots of alcohol which is unbranded and not well investigated. If you see the percentage of such as South Africa's whisky it has 43 and the Angolan one has 40 which shows that if you drink it you create an addiction to it, you will be drowned into it. Many people cross then borders to go and get alcohol. The border is too open, alcohol is coming from there". 
The porousness of the Oshikango border post is revealed as a risk factor for youth to indulge in alcohol abuse. According to Ananias et al. (2019), due to the poor border controls, alcohol and other substances are more likely to cross the border to the other country and be of use to youth. Peltzer, Ramlagan, Johnson and Phaswana-Mafuya (2010) confirm this by stating that poorly controlled border posts that also have a large number of people crossing a border offer opportunities for smuggling illegal substances, such as alcohol.

\subsection{Poverty and Unemployment}

From the three sets of data, some NGOs personnel, social workers and pastors have stated poverty and unemployment as a risk factor which predispose youth to abuse alcohol. It was indicated that if young people do not have jobs to keep them busy, they are more likely to stay at the alcohol outlets for the whole day and later resort to drinking alcohol and that ultimately becomes their habit. Other participants have indicated that, poverty through unemployment predisposed youth to drink alcohol. For example, it was stated that female youth who come from poor backgrounds are more likely to abuse alcohol by finding themselves old men who can meet their economic/financial needs.

One participant echoed that:

"Most of them are coming from very poor background and most of them are hungry because even the tax drivers said that if you buy the girl a Russian and chips from Ka mini for example, it is fine you can be with them".

In the same wavelength, one pastor said:

"And other things, maybe for the youth let us talk also that some are drinking because they believe that they have finished schooling and they have nowhere to go Let me say some have failed grades 12, other have failed grade 10 and have no jobs, so, they realise that what else would I do, I only have to drink".

Poverty and unemployment was found to be a risk factor amongst youth at Oshikango to indulge in alcohol abuse. This is supported by Setlalentoa et al. (2015) who established from their study in the selected communities with low socio-economic status that poverty prevails in such communities and because of the unemployment status, and not having anything to keep them busy, they engage in binge drinking. Matlakala (2018) also supports this sentiment that unemployment is associated with an increase of alcohol abuse. The researchers are of the view that when one does not have anything to keep them busy during the day, they are more likely to associate themselves with other members within their communities who might lead them to drinking behaviours.

\subsection{Affordable Price of Alcohol}

Some pastors and NGOs personnel have mentioned the affordable price of alcohol at Oshikango as a risk factor to predispose youth to alcohol abuse. These participants have indicated that alcohol and other drugs at Oshikango are sold at a very cheap price that even citizens that are not working can afford them.

This was explained by the participant who said:

"The like of tombo. Tombo is very cheap".

In the same wavelength, the other participant said:

"Because even drugs which are brought here, in Oshikango drugs are being sold very cheap".

Findings show the affordability of alcohol as a risk factor for youth to indulge in alcohol abuse. This is in agreement with Ayuka et al.'s (2014) argument that in the instances where alcohol is cheap, there is a high consumption by young people. Matlakala (2018) postulates that the price of alcohol has a role on the consumption amongst youth. He states that where alcohol prices increase, the consumption decreases and where the price decreases, to consumption goes up. This sentiments emphasise that there is a nexus between the price of alcohol and young people's possibility of consuming alcohol.

\subsection{Free Space From Parents}

Social Workers have reported that from their caseloads, they have youth who indulge in alcohol abuse because of pursuing their education far from their homes. It was indicated that such youth have a free space without parental supervision and attachment. This supports Thatcher and Clark (2008) who established young people who are not attached to their parents and are without parental supervision are more likely to indulge in alcohol consumption.

In corroboration of this, the other social worker posited that:

"I just want to add like, here at Oshikango there is a school called Elitte tutorial. They are coming here from different Regions, but most of them are coming from this Region, so when they came here they have to stay alone, they are renting, some are in the hostels, now some of the them said they don't have enough food, some of them they 
want to look like others, so they are going out with married people and drink alcohol because their parents do not see them"

It can be concluded for this that lack of parental supervision amongst youth afford them a free space to indulge in alcohol abuse. According to Matlakala (2018) in the instances where there is visible adult supervision around, youth is more likely to be free and engage in alcohol abuse.

\section{Conclusion}

The results of this study show that the abuse of alcohol in the northern region of the Republic Namibia is flexible. Young people and children in this area abuse alcohol autonomously without precautions. The flexibility of how alcohol abuse is not managed or controlled in the northern region of Namibia renders youth in that area at risk of being alcohol abusers which is a global concern. Therefore, families, the community, and various stakeholders need to collaborate their efforts to deal with alcohol abuse in the northern region of Namibia so as to have great citizens of the future from youth in the area. There should be strict law enforcement on the selling of alcohol within the communities in the northern regions of Namibia. Families and communities should also be empowered on general substance abuse and the danger in has on them and their children so as not to make alcohol available and accessible to their children. The security at the Oshikango border post needs to be tightened and be monitored to avoid young people and other adults from crossing to Angola without legal documents and security check. Further studies such as this which will involve parents, law enforcement officers, young people themselves, and the traditional authorities and other relevant key informants should be conducted. There should also be other studies at the other African border posts such as in Angola to fight the porousness of border posts as illegal substances are illegally imported to the other countries.

\section{Acknowledgements}

This study was wholly funded by the National Commission on Research Science and Technology of Namibia and the National Research Foundation of South Africa.

\section{Competing Interests Statement}

The authors declare that there are no competing or potential conflicts of interest.

\section{References}

Allan, A., Roberts, M. C., Allan, M. M., Pienaar, W. P., \& Stein, D. J. (2001). Intoxication, criminal offences and suicide attempts in a group of South African Problem drinkers. South African Medical Journal, 92, 145-150.

Ananias, J. A., Makhubele, J. C., Hasheela, M. W., Hamuse, T. N. I., Freeman, R. J., Mafa, P., ... Svinurai, A. (2019). Views of Teachers and Hostel Matrons on the Landscape of Substance Abuse amongst the Youth in the Northern Region of Namibia. Global Journal of Health Science, 11(5), 133-143. https://doi.org/10.5539/gjhs.v11n5p133

Ayuka, F., Barnett, R., \& Pearce, J. (2014). Neighbourhood Availability of Alcohol Outlets and Hazardous Alcohol Consumption in New Zealand. Health \& Place, 29, 186-199. PMid: 25128780. https://doi.org/10.1016/j.healthplace.2014.07.002

Babor, T. F., Caulkins, J. P., Edwards, G., Fischer, B., Foxcroft, D. R., Humphreys, K., \& Reuter, P. (2010). Drug policy and the public good. Oxford university press. https://doi.org/10.1093/acprof:oso/9780199557127.001.0001

Blumstein, A. (2002). Youth, guns and violence. Future child, 12, 38-53. PMid:12194611. https://doi.org/10.2307/1602737

Brady, K. T., \& Sonne, S. C. (1999). The role of stress in alcohol use, alcoholism treatment, and relapse. Alcohol Research, 23(4), 263.

Braun, V., \& Clarke, V. (2006). Using thematic analysis in psychology. Qualitative research in psychology, 3(2), 77-101. https://doi.org/10.1191/1478088706qp063oa

Brook, J. S., Cohen, P., \& Brook, D. W. (1998). Longitudinal study of co-occurring psychiatric disorders and substance use. Journal of the American Academy of Child \& Adolescent Psychiatry, 37(3), 322-330. PMid:9519638. https://doi.org/10.1097/00004583-199803000-00018

Constantinescu, M., \& Constantinescu, C. (2012). Success local policies in preventing and reducing the alcohol consumption among youngters. Review of research and social intervention, 36, 54-73.

Dishion, T. J., Véronneau, M. H., \& Myers, M. W. (2010). Cascading peer dynamics underlying the progression 
from problem behavior to violence in early to late adolescence. Development and psychopathology, 22(3), 603-619. PMid:20576182. https://doi.org/10.1017/S0954579410000313

Fergusson, D. M., \& Horwood, L. J. (2000). Does cannabis use encourage other forms of illicit drug use? Addiction, 95(4), 505-520. PMid:10829327. https://doi.org/10.1046/j.1360-0443.2000.9545053.x

Forster, J. L., Murray, D. M., Wolfson, M., \& Wagenaar, A. C. (1995). Commercial availability of alcohol to young people: results of alcohol purchase attempts. Preventive medicine, 24(4), 342-347. https://doi.org/10.1006/pmed.1995.1056

Franklin, C., \& Jordan, C. (1999). Family practice: Brief systems methods for social work. Brooks/Cole Pub.

Grayson, C. E., \& Nolen-Hoeksema, S. (2005). Motives to drink as mediators between childhood sexual assault and alcohol problems in adult women. Journal of traumatic stress, 18(2), 137-145. PMid:16281206. https://doi.org/10.1002/jts.20021

Government of the Republic of Namibia. (1998). Liquor Act 6 of 1998. Windhoek, Namibia: Government of Namibia.

Guillén, N., Roth, E., Alfaro, A., \& Fernández, E. (2015). Youth alcohol drinking behavior: Associated risk and protective factors. Revista Iberoamericana de Psicología y Salud, 6(2), 53-63. https://doi.org/10.1016/j.rips.2015.03.001

Hayes, L., Smart, D., Toumbourou, J. W., \& Sanson, A. (2004). Parenting Influences on Adolescent Alcohol Use. Melbourne: Australian Institute of Family Studies, 104.

Jackson, J. S., Knight, K. M., \& Rafferty, J. A. (2010). Race and unhealthy behaviors: chronic stress, the HPA axis, and physical and mental health disparities over the life course. American journal of public health, 100(5), 933-939. PMid:19846689. PMCid:PMC2853611. https://doi.org/10.2105/AJPH.2008.143446

Jernigan, D. H., \& World Health Organization. (2001). Global status report: alcohol and young people (No. WHO/MSD/MSB/01.1). Geneva: World Health Organization.

Kachur, S. P., Stennies, G. M., Powell, K. E., Modzeleski, W., Stephens, R., Murphy, R., \& Lowry, R. (1996). School-associated violent deaths in the United States, 1992 to 1994. Jama, 275(22), 1729-1733. PMid:8637169. https://doi.org/10.1001/jama.1996.03530460033027

Karger, H. (2000). American social welfare policy: A pluralist approach. New York: Longman.

Kauaria, L N., Kaundjua, M. B., \& Mufune, P. (2015). Drinking and its effects on risk behaviour amongst secondary school going youth in Windhoek. Journal for Studies in Humanities and Social Sciences, 4(1), 2026-7215.

Komro, K. A., Maldonado-Molina, M. M., Tobler, A. L., Bonds, J. R., \& Muller, K. E. (2007). Effects of home access and availability of alcohol on young adolescents' alcohol use. Addiction, 102(10), 1597-1608. PMid:17854336. https://doi.org/10.1111/j.1360-0443.2007.01941.x

Lowry, R., Powell, K. E., Kann, L., Collins, J. L, \& Kolbe, L. J. (1998). Weapon carrying, physical Fighting and fight related Injury among US adolescents. American Journal of Prevention. Medicine, 14, 122-129. https://doi.org/10.1016/S0749-3797(97)00020-2

Lynskey, M., White, V., Hill, D., Letcher, T., \& Hall, W. (1999). Prevalence of illicit drug use among youth: results from the Australian school students' alcohol and drugs survey. Australian and New Zealand Journal of Public Health, 23(5), 519-524. PMid:10575775. https://doi.org/10.1111/j.1467-842X.1999.tb01309.x

Macy, R. J., Renz, C., \& Pelino, E. (2013). Partner violence and substance abuse are intertwined: Women's perceptions of violence-substance connections. Violence Against Women, 19(7), 881-902. PMid:23955931. https://doi.org/10.1177/1077801213498208

Maree, M., Ananias, J., Lightfoot, E., Katondoka, K., \& Ashton, D. (2008). Factors leading to drug and alcohol use and abuse by Namdeb employees: A comprehensive mixed-methods investigation. Unpublished research report.

Masemola, E., van Aardt, C. J., \& Coetzee, M. C. (2012). Income and Expenditure of Household in South Africa. The Bureau of Market Research (BMR), University of South Africa (UNISA), Research Report 429.

Matlakala, F. K. (2018). Risk factors of alcohol abuse amongst the youth in Musina town, Limpopo province (Masters dissertation, University of Limpopo). 
Matlakala, F. K., Makhubele, J. C., Hasheela, M. W., Ananias, J. A., Rapholo, S. F., Svinurai, A., ... \& Hamuse,T. N. I. (2019). Religious leaders perspective on the effects of 'hitting the bottle hard' amongst the youth in Musina town, Limpopo province. Journal of Social Science and Humanities, 16(4), 1-11.

Meghdadpour, S., Curtis, S., Pettifor, A., \& MacPhail, C. (2012). Factors associated with substance use among orphaned and non-orphaned youth in South Africa. Journal of adolescence, 35(5), 1329-1340. PMid:22704785. https://doi.org/10.1016/j.adolescence.2012.05.005

Milam, A. J., Lindstrom-Johnson, S., Furr-Holden, C. D. M., \& Bradshaw, C. P. (2016). Alcohol outlet density and substance use amongst high scholars. Journal of Community Psychology, 44(7), 819-832. https://doi.org/10.1002/jcop.21802

Miley, K., O'Melia, M., \& DuBois, B. (2001). Generalist social work practice: An empowering profession. Boston: Allyn \& Bacon.

Mudhovozi, P., Maunganidze, L., Maseko, M., Ngwenya, F., \& Netshikweta, L. M. (2014). Patterns of substance abuse among high school students. African Journal for Physical, Health Education, Recreation and Dance, 1(2), 348-358.

National Drug Master Plan: 2006 - 2011. Pretoria: Department of Social Development - Government Printers.

Ndondo, B. (2016). A literature review on drug and substance use amongst youth and young women in South Africa. Soul City Institute Drug Abuse Youth South Africa Final. Retrieved 10 January, 2019, from https://www.soulcity.org.za/resources/research/literature-reviews/soul-city-institute-drug-abuse-youth-south -africa.pdf/view

Neuman, W. L. (2000). Social research methods: qualitative and quantitative approaches (4th ed.). Boston: Allyn \& Bacon. https://doi.org/10.1557/PROC-660-JJ8.30.1

Nowak, M., Papiernik, M., Mikulska, A., \& Czarkowska-Paczek, B. (2018). Smoking, alcohol consumption, and illicit substances use among adolescents in Poland. Substance Abuse Treatment, Prevention, and Policy, 13(1), 42. https://doi.org/10.1186/s13011-018-0179-9

Parry, C. D. H., Myers, B., Morojele, N. K., Flisher, A. J., Bhana, A., Donson, H., \& Plüddemann, A. (2004). Trends in adolescent alcohol and other drug use: findings from three sentinel sites in South Africa (1997-2001). Journal of Adolescence, 27, 429-440. PMid:15288752. https://doi.org/10.1016/j.adolescence.2003.11.013

Patrick, M. E., Maggs, J. L., \& Lefkowitz, E. S. (2015). Daily associations between drinking and sex among college students: A longitudinal measurement burst design. Journal of Research on Adolescence, 25(2), 377-386. PMid:26052189 PMCid:PMC4452129. https://doi.org/10.1111/jora.12135

Peltzer, K., Ramlagan, S., Johnson, B. D., \& Phaswana-Mafuya, N. (2010). Illicit drug use and treatment in South Africa: a review. Substance use \& misuse, 45(13), 2221-2243. PMid:21039113; PMCid:PMC3010753. https://doi.org/10.3109/10826084.2010.481594

Potgieter, M. C. (1998). The social work process: Development to empower people. Prentice Hall South Africa.

Robinson, E., Oldham, M., Sharps, M., Cunliffe, A., Scott, J., Clark, E., \& Field, M. (2016). Social imitation of alcohol consumption and ingratiation motives in young adults. Psychology of addictive behaviors, 30(4), 442. PMid:27322802; PMCid:PMC4913807. https://doi.org/10.1037/adb0000150

Salanţă, L. C., Tofană, M., Pop, C. R., Pop, A., Coldea, T., \& Mihai, M. (2018). Risk Factors Associated with Alcohol Consumption Among Romanian University Students-Preliminary Research. Bulletin UASVM Food Science and Technology, 75, 1. https://doi.org/10.15835/buasvmen-fst:0025

Setlalentoa, M., Ryke, E., \& Strydom, H. (2015). Intervention Strategies Used to Address Alcohol abuse in the North West province, South Africa. Social Work, 51(1), 80-100. https://doi.org/10.15270/51-1-429

Shilakwe, D. (2005). The Effects of Parental Alcohol Abuse on Children (Doctoral dissertation (Masters Dissertation. South Africa: University of Venda).

Shikoyeni, H. N. (2017). Exploring the psycho social determinants of heavy alcohol drinking amongst women in Oshana, Namibia (MA thesis, University of Western Cape, Cape Town, South Africa) Retrieved from http://hdl.handle.net/11394/5621

Steinglass, P. (1987). The alcoholic family. New York: Basic Books. 
Thobejane, T., \& Raselekoane, R. (2017). Probing Alcohol Abuse amongst the Youth of Musina Community in Limpopo Province of South Africa. Stud Tribes Tribals, 15(2), 94-102.

Thrul, J., \& Kuntsche, E. (2015). The impact of friends on young adults' drinking over the course of the evening-an event-level analysis. Addiction, 110(4), 619-626. PMid:25732756. https://doi.org/10.1111/add.12862

United Nations Development Programme [UNDP]. (1999). Namibia Human Development Report. Windhoek, Namibia: United Nations Development Programme.

United Nations Office on Drugs and Crime. (2009). World Drug Report. Available on Urban \& Development Bulletin, 2.

World Health Organisation. (2011). Global status report on alcohol and health. WHO press.

\section{Copyrights}

Copyright for this article is retained by the author(s), with first publication rights granted to the journal.

This is an open-access article distributed under the terms and conditions of the Creative Commons Attribution license (http://creativecommons.org/licenses/by/4.0/). 